\title{
Ethylene absorbents influence fruit firmness and activity of enzymes involved in fruit softening of Japanese plum (Prunus salicina Lindell) cv. Santa Rosa
}

Swati SHARmA ${ }^{1}$, Ram Roshan SHARMA ${ }^{1 *}$, Ram Krishna PAL ${ }^{1}$, Md. Jameel JHALEGAR ${ }^{1}$, Jagvir Singh ${ }^{1}$, Manish SRIVASTAV ${ }^{2}$, Mast Ram DHIMAN ${ }^{3}$

${ }^{1}$ Div. Post Harvest Technol., Indian Agric. Res. Inst., New Delhi, 110 012, India, rrs_fht@rediffmail.com

${ }^{2}$ Div. Fruits Hortic. Technol., IARI, New Delhi, India

${ }^{3}$ IARI Reg. Stn., Katrain (Himachal Pradesh), India
* Correspondence and reprints

Received 7 September 2011 Accepted 15 December 2011

Fruits, 2012, vol. 67, p. 257-266 (C) 2012 Cirad/EDP Sciences All rights reserved DOI: 10.1051/fruits/2012021 www.fruits-journal.org

RESUMEN EsPaÑOL, p. 266
Ethylene absorbents influence fruit firmness and activity of enzymes involved in fruit softening of Japanese plum (Prunus salicina Lindell) cv. Santa Rosa.

Abstract - Introduction. Plum cv. Santa Rosa shows climacteric behaviour and grows profitably under sub-temperate conditions in India. After ripening, it has a very limited shelf life (3-4 days) in ambient conditions $\left[(38 \pm 2){ }^{\circ} \mathrm{C}\right.$ and at $\left.(68 \pm 4) \% \mathrm{RH}\right]$. Hence, there is an urgent need to extend its marketability using recent techniques. Materials and methods. Plums were harvested at the pre-climacteric and climacteric stages of maturity and packed with newspaper shreds (control), $\mathrm{KMnO}_{4^{-}}$ impregnated chalks, $\mathrm{KMnO}_{4}$-impregnated newspaper shreds or ethylene-absorbent sachets; then they were transported by road to New Delhi. The biochemical and physiological analyses were carried out at 3-day intervals on plums stored in supermarket conditions $\left[(20 \pm 1){ }^{\circ} \mathrm{C}\right.$ and at $\left.(90 \pm 2) \% \mathrm{RH}\right]$ for 15 days. Results and discussion. Untreated fruits had less firmness than those which were packed with ethylene absorbents. The activities of fruit-softening enzymes such as lipoxygenase (LOX), polygalacturonase (PG) and pectin methylesterase (PME) increased rapidly in the control treatment in comparison with plums packed with various ethylene absorbents, the least being either with ethyleneabsorbent sachets or with $\mathrm{KMnO}_{4}$-impregnated newspaper shreds. Plums of pre-climacteric and climacteric maturity attained respiration and ethylene evolution peaks on the 9th day and 6th day, respectively. Conclusions. The plums of pre-climacteric and climacteric stages of maturity packed with ethylene-absorbent sachets showed the best results in supermarket conditions in maintaining the firmness, quality and shelf life of plum up to the 12th day and 9th day of storage, respectively.

India / Prunus salicina / fruits / keeping quality / firmness / ethylene production / postharvest physiology / enzyme activity / lipoxygenase / polygalacturonase / esterases

Les absorbeurs d'éthylène influencent la fermeté du fruit et l'activité des enzymes impliqués dans le ramollissement de la prune japonaise (Prunus salicina Lindell) cv. Santa Rosa.

Résumé - Introduction. La prune japonaise cv. Santa Rosa a un comportement climatérique et se développe bien en conditions sous-tempérées en Inde. Après maturation, elle a une durée de vie très limitée (3-4 jours) dans les conditions ambiantes [ $(38 \pm 2){ }^{\circ} \mathrm{C}$ et $(68 \pm 4) \% \mathrm{RH}$. Il serait donc urgent d'étendre sa durée de commercialisation à l'aide de techniques récentes. Matériel et méthodes. Des prunes japonaises ont été récoltées aux stades de maturité pré-climatérique et climatérique et emballées avec des lanières de journaux (traitement témoin), des craies imprégnées de $\mathrm{KMnO}_{4}$, des lanières de journaux imprégnées de $\mathrm{KMnO}_{4}$ ou des sachets absorbeurs d'éthylène, puis elles ont été transportées par la route à New Delhi. Des analyses biochimique et physiologique ont été effectuées à 3 jours d'intervalle sur les prunes stockées dans des conditions de supermarchés $\left[(20 \pm 1)^{\circ} \mathrm{C}\right.$ et $(90 \pm 2) \% \mathrm{RH}$ ] pendant 15 jours. Résultats et discussion. Les fruits sans absorbeurs d'éthylène ont été moins fermes que ceux qui ont été emballés avec des matériaux absorbeurs d'éthylène. Les activités des enzymes de ramollissement des fruits comme la lipoxygénase (LOX), la polygalacturonase (PG) et la pectine méthylestérase (PME) ont augmenté rapidement dans les fruits témoins par rapport à ceux qui avaient été emballés avec les différents matériaux absorbeurs d'éthylène, ces activités étant moindres pour les prunes emballées soit avec les sachets d'absorbeurs d'éthylène, soit avec des lanières de journaux imprégnées de $\mathrm{KMnO}_{4}$. Les prunes aux stades de maturité pré-climatérique et climatérique ont atteint leurs pics de respiration et d'évolution de l'éthylène le 9e jour et Ge jour, respectivement. Conclusion. Les prunes japonaises récoltées à des stades de maturité pré-climatérique et climatérique, emballées en présence de sachets absorbeurs d'éthylène et stockées en conditions de supermarchés, ont donné les meilleurs résultats pour le maintien de la fermeté, de la qualité et de la durée de vie des fruits jusqu'au $12^{\mathrm{e}}$ jour et $9^{\mathrm{e}}$ jour de stockage, respectivement.

Inde / Prunus salicina / fruits / aptitude à la conservation / fermeté / production d'éthylène / physiologie après récolte / activité enzymatique / lipoxygénase / polygalacturonase / estérase 


\section{Introduction}

The climatic conditions of India favour the cultivation of Japanese plum (Prunus salicina) because this species is basically hardy in nature and thrives well under adverse edaphic and climatic conditions. In India, Japanese plum varieties such as Beauty, Mariposa and Santa Rosa are grown commercially under sub-temperate climatic conditions, but Santa Rosa dominates because of its self-fruitfulness, prolific bearing habit and because of having a characteristic flavour [1].

Plum cv. Santa Rosa is climacteric in nature and does not attain full ripe edible quality on the tree at harvest. However, for nearby markets, plums are harvested at the climacteric (ready-to-eat) stage of maturity and, for distant markets, they are harvested at the pre-climacteric (ready-to-ripen) stage. Plums harvested at the climacteric stage usually attain an attractive peel colour and have better flavour than those harvested at the pre-climacteric stage. Thus, the stage of maturity at which fruits are harvested may also have a significant influence on colour, texture, fruit softening, enzyme activity and postharvest quality attributes [2]. Further, the perishable nature of ripe plum fruit poses a serious problem for its storage, transport and marketing. The main reason for its limited cultivation in the subtropical areas is the poor keeping quality of its fruit. Storage in a fresh condition for an extended period without loss in quality is therefore a very pressing problem [1]. Postharvest physiochemical changes associated with fruit ripening in plum include fruit softening, and changes in fruit skin colour, fruit texture, aroma volatiles and flavour, which are controlled by endogenous ethylene production [3-5].

After ripening, plum has a limited shelf life of about 3-4 days only in ambient conditions $\left[(38 \pm 2){ }^{\circ} \mathrm{C}\right.$ and at $\left.(68 \pm 4) \% \mathrm{RH}\right]$. Under cold storage conditions $\left[0-1{ }^{\circ} \mathrm{C}\right.$ and (90 \pm 5$) \% \mathrm{RH}$ ], it can be stored for about 1820 days. Postharvest softening is a major factor limiting the shipping, storage and shelf life of plums. Their shelf life is further reduced drastically due to rough handling and poor storage conditions. Thus, such an important and valuable fruit remains in the market for a very limited period, and there is an urgent need to extend its availability through proper postharvest management practices. Among different postharvest management strategies of fresh fruit handling, use of ethylene absorbents has been reported to be very useful $[6,7]$.

Ethylene absorbents usually contain potassium permanganate which, when placed inside a packaging box, oxidises ethylene to $\mathrm{CO}_{2}$ and water. As a result, the deleterious effects of ethylene on fruit ripening, softening or postharvest quality are delayed, and ultimately the postharvest shelf or storage life of fruits is increased drastically, which helps in extending the marketability of fruits for a longer time [8, 9].

The major objective of our study was to investigate, during transportation, the effect of placement of ethylene absorbents in packed plums on several physiological and biochemical attributes of plum fruits, which are indicators of fruit softening, ripening and overall fruit quality for wholesale marketing.

\section{Materials and methods}

\subsection{Fruit material}

Plums cv. Santa Rosa were harvested at two stages of maturity, i.e., pre-climacteric (ready-to-ripen) and climacteric (ready-toeat), in the month of June from a private orchard in Katrain, Kullu (Himachal Pradesh, India). The fruits were sorted, graded, and packed in corrugated fibreboard boxes cushioned either with various ethylene absorbents or with newspaper shreds only (control). They were then transported to the Division of Postharvest Technology, Indian Agricultural Research Institute (IARI), New Delhi, India, by road in about $15 \mathrm{~h}$. In the laboratory, fruits were again sorted to remove bruised and defective ones and then stored in supermarket conditions $\left[(20 \pm 1){ }^{\circ} \mathrm{C}\right.$ and at $\left.(90 \pm 2) \% \mathrm{RH}\right]$ for 15 days. 


\subsection{Use of ethylene absorbents, methodology and observations recorded}

The fruits of plum cv. Santa Rosa were divided into four lots and each lot (treatment) contained 120 fruits, with five replications. Three ethylene absorbents: potassium permanganate $\left(\mathrm{KMnO}_{4}\right)$-impregnated chalks, $\mathrm{KMnO}_{4}$-impregnated newspaper shreds and ethylene-absorbent sachets were placed in the boxes. $\mathrm{KMnO}_{4}$-impregnated chalks and newspaper shreds were prepared by soaking them in a saturated solution of $\mathrm{KMnO}_{4}$ for half an hour and subsequently drying them under a ceiling fan. Ethylene-absorbent sachets were used as such, the samples of which were received free of cost. The different ethylene absorbents were placed at the bottom, between layers and at the top of the packing box before transportation to New Delhi by road in about $15 \mathrm{~h}$. In the lab in New Delhi, observations were recorded on fruit firmness, respiration rate, ethylene rate, and lipoxygenase, polygalacturonase and pectin methylesterase activities, which were recorded at 3-day intervals.

\subsection{Characteristic measurement}

\subsubsection{Fruit firmness}

Fruit firmness was determined using a texture analyser (model: TA+Di, Stable Micro Systems, UK) using a compression test and represented as $\mathrm{N}$ (Newton).

\subsubsection{Respiration rate and ethylene evolution}

Ethylene production and respiration rates were measured using the static headspace technique. Five fruits from each replication were selected at random and enclosed in a hermetically sealed container $(1,000 \mathrm{~mL})$ fitted with a silicon rubber septum for $1 \mathrm{~h}$.

The concentrations of $\mathrm{O}_{2}$ and $\mathrm{CO}_{2}$ were recorded in the headspace of the container using an auto gas analyser (Model: Checkmate $9900 \mathrm{O}_{2} / \mathrm{CO}_{2}$, PBI Dan sensor, Denmark) and expressed as $\mathrm{mL} \mathrm{CO} 2 \cdot \mathrm{kg}^{-1} \cdot \mathrm{h}^{-1}$.
To determine ethylene, one $\mathrm{mL}$ of the headspace atmosphere of the container was withdrawn with a gas-tight syringe and injected into a gas chromatograph (Model HP 5890, Hewlett Packard, USA), which was calibrated using standard ethylene gas (Laser Gases, New Delhi, India). The gas chromatograph was equipped with a Porapak-N (80-100 mesh) column and a flame ionisation detector (FID). Nitrogen was used as the carrier gas at a flow rate of $30 \mathrm{~mL} \cdot \mathrm{min}^{-1}$, while hydrogen and air were used as fuel gases at flow rates of ( 25 and 250) $\mathrm{mL} \cdot \mathrm{min}^{-1}$, respectively. The temperatures in the injector, column and detector were maintained at $(110,60 \text { and } 275)^{\circ} \mathrm{C}$, respectively, and the rate of ethylene evolution was expressed as $\mu \mathrm{L} \cdot \mathrm{kg}^{-1}$ of fruit fresh weight $\cdot h^{-1}$.

\subsubsection{Lipoxygenase activity}

Lipoxygenase (LOX) activity in plum was measured by following the method of Jhalegar et al. [10] with minor modifications. First, one gram of fruit pulp was weighed and homogenised in $10 \mathrm{~mL}$ EDTA in a prechilled pestle and mortar. The homogenate was centrifuged at $15,000 \times g$ for $20 \mathrm{~min}$ at $4^{\circ} \mathrm{C}$ and the supernatant was used for assay of lipoxygenase activity. Enzyme assay was carried out by taking $50 \mu \mathrm{L}$ enzyme extract and $2.5 \mathrm{~mL}$ of substrate solution in a cuvette. The absorbance was recorded at $234 \mathrm{~nm}$ in a spectrophotometer (double beam UV-VIS spectrophotometer UV5704SS). The blank was prepared by using substrate solution and the substrate was prepared by taking $35 \mu \mathrm{L}$ Tween-20 in a beaker. To this, twentyfive $\mu \mathrm{L}$ of linoleic acid was added. To dissolve it completely, $1 \mathrm{~mL}$ of $0.2 \mathrm{M} \mathrm{NaOH}$ was added. Once all of the linoleic acid was dissolved, the final volume was made up to $100 \mathrm{~mL}$ by using $0.1 \mathrm{M}$ phosphate buffer (pH 6.5) and then the $\mathrm{pH}$ was brought down to 6.5 by adding $0.2 \mathrm{M} \mathrm{HCl}$. The LOX activity was expressed as $\mu \mathrm{mol} \cdot \mathrm{g}^{-1}$ of fruit fresh weight $\cdot \mathrm{min}^{-1}$.

\subsubsection{Polygalacturonase activity}

Polygalacturonase (PG) activity was measured by following the method of Lazan et al. [11] with minor modifications. Enzyme extract was prepared by taking one gram of 
Figure 1.

Effect of ethylene absorbents on firmness of Japanese plum cv. 'Santa Rosa', according to the pre-climacteric or climacteric stage of maturity. The fruits were packed with ethylene absorbents during transportation, after about $4 \mathrm{~h}$ of harvesting. After treatment, fruits were transported by road for about $15 \mathrm{~h}$ and then stored in the lab for 15 days in supermarket conditions $\left[(20 \pm 1){ }^{\circ} \mathrm{C}\right.$ and at $(90 \pm 2) \%$ $\mathrm{RH})$ ]. The data are means of five samples (fruits) with three replications, recorded at 3-day intervals. The bars represent the mean \pm standard error.

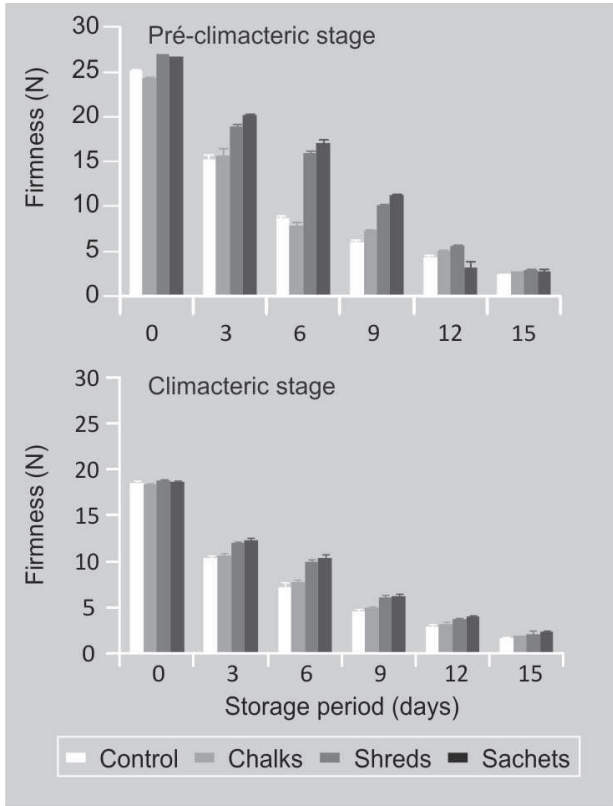

fruit and homogenising it in $10 \mathrm{~mL}$ of sodium acetate buffer (0.2 M; pH 6.0) with $20 \mathrm{mg}$ of $\mathrm{Na}_{2} \mathrm{~S}_{2} \mathrm{O}_{4}$ and polyvinyl pyrrolidine (PVP) in a pre-chilled pestle and mortar. The homogenate was centrifuged at $15,000 \times g$ for 20 min at $4{ }^{\circ} \mathrm{C}$ and the supernatant was used for the assay of PG activity. The polygalacturonase enzyme assay mixture consisted of $0.45 \mathrm{~g}$ of pectin and $0.1 \mathrm{~g}$ casein, which were dissolved in $0.4 \%$ sodium acetate buffer ( $\mathrm{pH} 3.8$ ). This solution was diluted to $100 \mathrm{~mL}$ with $0.4 \%$ sodium acetate buffer ( $\mathrm{pH}$ 3.8). To measure the PG enzyme activity, $0.2 \mathrm{~mL}$ of enzyme extract was added to $2 \mathrm{~mL}$ of assay mixture and incubated at $37^{\circ} \mathrm{C}$ for $2 \mathrm{~h}$. From this incubated mixture, $0.05 \mathrm{~mL}$ was added to $1 \mathrm{~mL}$ of $5 \%$ phenol, to which $5 \mathrm{~mL}$ of $96 \% \mathrm{H}_{2} \mathrm{SO}_{4}$ were poured and allowed to react for $15 \mathrm{~min}$. The contents were diluted with $5 \mathrm{~mL}$ of distilled water, mixed thoroughly and cooled down to room temperature. The absorbance was recorded at $490 \mathrm{~nm}$ in a spectrophotometer (double beam UV-VIS spectrophotometer UV5704SS). The blank was prepared by adding distilled water instead of enzyme extract to the assay mixture. The PG activity was expressed as $(288.07 \times$ OD $) \mu \mathrm{g}$ galacturonic acid $\cdot \mathrm{g}^{-1}$ fruit fresh weight $\mathrm{h}^{-1}$.

\subsubsection{Pectin methylesterase activity}

Pectin methylesterase (PME) activity in plums was measured by following the method of Hagerman and Austin [12] with minor modifications. For enzyme assay, five $\mathrm{g}$ of fruit pulp were homogenised in $15 \mathrm{~mL}$ cold $\left(4^{\circ} \mathrm{C}\right) 8.8 \% \mathrm{NaCl}$ using a pestle and mortar. The homogenate was then centrifuged at $15,000 \times g$ for $15 \mathrm{~min}$. The supernatant was collected and its $\mathrm{pH}$ was adjusted to 7.5 with $\mathrm{NaOH}$, after which it was used for enzyme assay. In a cuvette, $2.0 \mathrm{~mL}$ of pectin was mixed with $0.15 \mathrm{~mL}$ of bromothymol blue and $0.83 \mathrm{~mL}$ of water. The absorbance of the mixture was read against water as a blank at $620 \mathrm{~nm}$. A constant value of $\mathrm{A}_{620}$ at this stage indicates that there is no non-enzymatic hydrolysis occurring. The reaction is started by adding $20 \mu \mathrm{L}$ of enzyme solution and the rate of decrease in $\mathrm{A}_{620}$ is recorded. The graph is plotted (OD $v s$. time) and the rate of reaction was determined from the linear portion of the graph. The PME activity was expressed as $\mu \mathrm{mol}$ of $\mathrm{NaOH} \cdot \mathrm{g}^{-1}$ fruit fresh weight $\cdot \mathrm{min}^{-1}$.

\subsection{Statistical design and analysis of data}

The experiments were laid out in a factorial Completely Randomised Design (CRD) with each treatment consisting of 120 fruits with five replications. The data obtained from the experiments were analysed by using SPSS 16.0 software and the results were compared from ANOVA by calculating the $\operatorname{LSD}(P \leq 0.05)[13]$.

\section{Results and discussion}

\subsection{Effects of ethylene absorbents on fruit firmness}

Fruit softening determines the quality and shelf life of the produce. All the ethylene absorbents $\left(\mathrm{KMnO}_{4}\right.$-impregnated chalks or newspaper shreds, and ethylene sachets), the stages of maturity at harvest and the duration of storage significantly influenced the fruit firmness in Santa Rosa plums 
(figure 1). The fruit firmness was significantly higher in plums harvested at the preclimacteric stage than in those harvested at the climacteric stage of maturity. In general, the fruit firmness was significantly lower in untreated plums at both stages of maturity than in those in which different ethylene absorbents were placed. However, the maximum fruit firmness was recorded in plums in which ethylene-absorbent sachets were placed. Plums in which $\mathrm{KMnO}_{4}$-impregnated chalks or newspaper shreds were placed showed intermediate results for fruit firmness at both stages of maturity $(P \leq$ 0.05). Fruit firmness in plums decreased progressively with the increase in storage period at both the stages of maturity, the minimum being on the 15 th day of storage.

Fruit firmness is an important characteristic, which governs the postharvest life of fresh horticultural produce. Lower firmness in plums of the climacteric stage of maturity may be ascribed to being metabolic active, and having higher respiration and ethylene evolution rates, as a result of which, such fruits tend to soften at a faster rate than plums of the pre-climacteric stage. Higher firmness in plums in which ethylene absorbents, primarily $\mathrm{KMnO}_{4}$-impregnated newspaper shreds or sachets were placed, may be due to their lower metabolic activities, rendering them less soft or firmer. Thakur et al. also reported that apples (Malus domestica Borkh. cv. Starking Delicious) placed in PE-lined CFB cartons with ethylene absorbents exhibited slower decrease in fruit firmness than control [8]. Similarly, Ishaq et al. reported that apricots, which received a treatment consisting of $\left[\mathrm{KMnO}_{4}\right.$ $+3 \% \mathrm{CaCl}_{2}+$ polyethylene bags], were firmer than untreated fruits [14]. Fruit firmness in plums decreased progressively with the increase in storage period at both the stages of maturity, primarily because there might have been progressive increase in fruit softening due to increased activities of PG and PME enzymes, rendering them much softer with the progressive increase in storage period. In general, fruit firmness decreases sharply with ripening, which is influenced by the stage at which fruits are harvested [2].

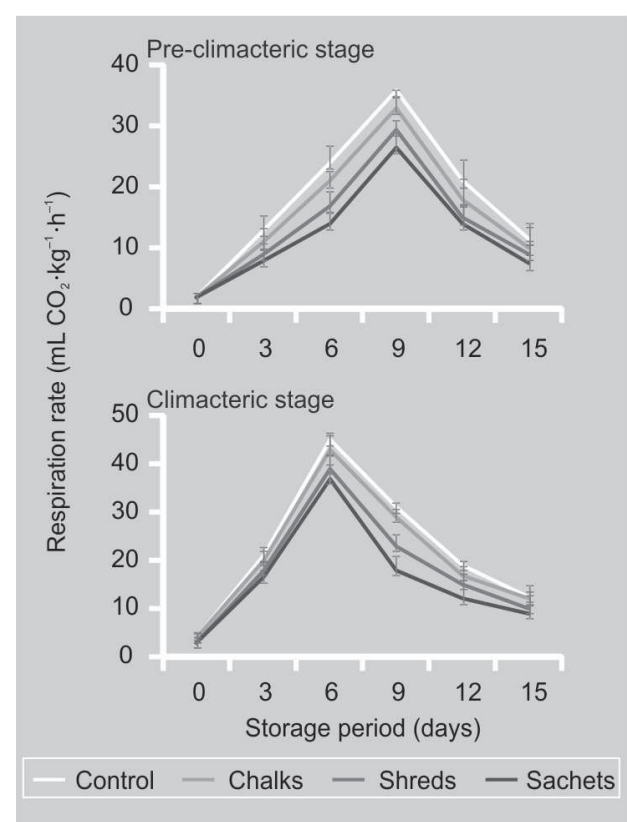

Figure 2.

Effect of ethylene absorbents on the respiration rate of Japanese plum cv. 'Santa Rosa', according to the preclimacteric or climacteric stage of maturity. The fruits were packed with ethylene absorbents during transportation, after about $4 \mathrm{~h}$ of harvesting. After treatment, fruits were transported by road for about $15 \mathrm{~h}$ and then stored in the lab for 15 days in supermarket conditions $\left[(20 \pm 1){ }^{\circ} \mathrm{C}\right.$ and at $(90 \pm 2) \%$ $\mathrm{RH})$ ].The data are means of five samples (fruits) with three replications, recorded at 3-day intervals. The bars represent the mean \pm standard error.

\subsection{Effects on respiration rate}

The respiration rate is a major metabolic process taking place in harvested produce. It is a vital process of life, directly linked to maturation, handling, transportation, and subsequent storage life. The respiration rate of the plums was significantly influenced by the stage of maturity, various ethylene absorbents and duration of storage (figure 2).

The respiration rate was significantly higher in plums harvested at the climacteric stage than in those harvested at the pre-climacteric stage of harvest. Further, plums in which ethylene-absorbent sachets were placed exhibited the lowest respiration rate at both stages of maturity. Interestingly, the untreated plums of the climacteric stage attained the respiratory peak of $(45 \mathrm{~mL}$ $\mathrm{CO}_{2} \cdot \mathrm{kg}^{-1} \cdot \mathrm{h}^{-1}$ ) on the 6th day, and those of the pre-climacteric stage on the 9th day of storage $\left(36 \mathrm{~mL} \mathrm{CO} \cdot \mathrm{kg}^{-1} \cdot \mathrm{h}^{-1}\right)$, and thereafter showed a declining trend in the respiration rate. However, in general, the respiratory peak in all the treatments of the climacteric stage of maturity was attained on the 6th day and that in the pre-climacteric stage on the 9th day of storage (figure 2). 


\section{S. Sharma et al.}

Figure 3.

Effect of ethylene absorbents on the ethylene evolution rate of Japanese plum cv. 'Santa Rosa', according to the preclimacteric or climacteric stage of maturity. The fruits were packed with ethylene absorbents during transportation, after about $4 \mathrm{~h}$ of harvesting. After treatment, fruits were transported by road for about $15 \mathrm{~h}$ and then stored in the lab for 15 days in supermarket conditions $\left[(20 \pm 1){ }^{\circ} \mathrm{C}\right.$ and at $(90 \pm 2) \%$ $\mathrm{RH})]$.The data are means of five samples (fruits) with three replications, recorded at 3-day intervals. The bars represent the mean \pm standard error.

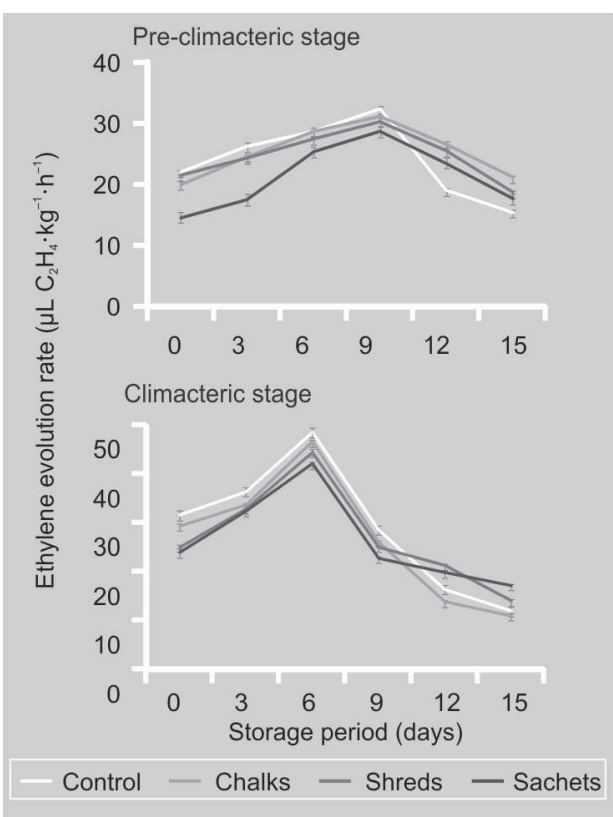

Further, irrespective of stage of maturity or treatment, in the climacteric stage, the respiration rate of the plums increased up to the 6th day of storage and then it declined, while, in the pre-climacteric stage, it increased up to the 9th day and then declined linearly. The $\mathrm{KMnO}_{4}$-impregnated newspaper shreds and chalks showed intermediate results for respiration rates (figure 2) $(P \leq 0.05)$.

The suppression of the respiration rate by ethylene absorbents in 'Santa Rosa' plums could be due to their action of scavenging the ethylene, which is known to trigger respiration in fruits, especially in the climacteric types. Patel and Rao reported several changes in physiological attributes in khirni with fruit growth and maturity [14]. Thus, our study is in accordance with the studies of Ishaq et al., who reported that cut slices of packed tomatoes containing purafil had more reduced rates of respiration than those in which no ethylene absorbent was used [15]. Pangaribuan et al. reported changes in ethylene evolution in tomato with different ethylene absorbents [16]. Similarly, Pekmezci et al. observed lower respiration rates in 'Hayward' kiwifruit when stored in a modified atmosphere along with ethylene absorbents than in control kiwifruits [17]. Similarly, Jang et al. reported that the stora- bility of 'Sheridan' and 'Muscat Bailey A' grapes was increased over untreated grapes when these were packed with ethylene absorbents [7].

Interestingly, the untreated plums of the climacteric stage attained the respiratory peak on the 6th day and those of the preclimacteric stage at the 9th day of storage. Delay in attaining the respiration peak in the pre-climacteric stage is attributed to lower metabolic activities in plums of pre-climacteric maturity than in those harvested at the climacteric stage of maturity.

\subsection{Effects on the rate of ethylene evolution}

Various ethylene absorbents, the stage of maturity and duration of storage significantly influenced the rate of ethylene evolution in plum (figure 3). Plums of the climacteric stage of maturity had a significantly higher ethylene evolution rate than those of the pre-climacteric stage. The untreated plums of both stages had a significantly higher ethylene evolution rate than those in which different ethylene absorbents were placed. Among the treatments, plums in which ethylene-absorbent sachets were placed exhibited a significantly lower ethylene evolution rate than the other treatments or control. Untreated plums of the climacteric stage of harvest maturity attained the ethylene evolution peak $(49.2 \mu \mathrm{L}$ $\mathrm{C}_{2} \mathrm{H}_{4} \cdot \mathrm{kg}^{-1} \cdot \mathrm{h}^{-1}$ ) on the 6th day and those of the pre-climacteric stage on the 9th day of storage $\left(36.2 \mu \mathrm{L} \mathrm{C}_{2} \mathrm{H}_{4} \cdot \mathrm{kg}^{-1} \cdot \mathrm{h}^{-1}\right)$. However, in general, the ethylene evolution peak in all the treatments of the climacteric stage of maturity was attained on the 6th day and that in the pre-climacteric stage on the 9th day of storage (figure 3). Irrespective of the stage of maturity or treatment, the ethylene evolution rate increased up to the 6th day of storage in plums of the climacteric stage, and to the 9th day in those of the pre-climacteric stage, and then it showed a declining trend.

The higher ethylene evolution rate in plums of the climacteric stage of maturity than in plums of the pre-climacteric stage may be attributed to the higher senescent 
nature of plums of this maturity group. Among the treatments, plums in which ethylene-absorbent sachets were placed exhibited a significantly lower ethylene evolution rate than the other treatments or control. The lower ethylene evolution rate in plums packed with ethylene absorbents might be due to the ethylene-absorbing capacity of the absorbent. Sachets proved better in this respect than $\mathrm{KMnO}_{4}$-impregnated shreds or chalks, indicating that sachets were more effective in absorbing the liberated ethylene, followed by $\mathrm{KMnO}_{4}$-impregnated shreds. The $\mathrm{KMnO}_{4}$-impregnated newspaper shreds and chalks showed intermediate results for ethylene evolution rates (figure 3) $(P \leq 0.05)$. Changes in physiological attributes in khirni with fruit growth and maturity were reported by Patel and Rao [14]. The effect of ethylene absorbents on the ethylene evolution rate in fruits has been studied by Pekmezci et al., who reported lower ethylene evolution rates in 'Hayward' kiwifruit when stored in a modified atmosphere along with ethylene absorbents than control kiwifruits [17]. Similarly, Jang et al. [6] reported that the storability of 'Sheridan' and 'Muscat Bailey A' grapes was increased over untreated grapes by reduced rates of ethylene evolution when ethylene absorbents were placed in the polyethylene bags containing grapes.

\subsection{Effects on biochemical parameters}

\subsubsection{Lipoxygenase activity}

Lipoxygenase (LOX) is considered as one of the major enzymes responsible for senescence and membrane deterioration in a number of plant tissues [18]. Lipoxygenase activity in 'Santa Rosa' plums was significantly affected by the maturity stage, treatment and duration of storage (figure 4). Whatever the treatment or storage duration, the lipoxygenase activity was significantly higher in plums harvested at the climacteric stage than in those harvested at the pre-climacteric stage of maturity (figure 4). In general, the lipoxygenase activity was significantly higher in untreated plums than in those in which different ethylene absorb-

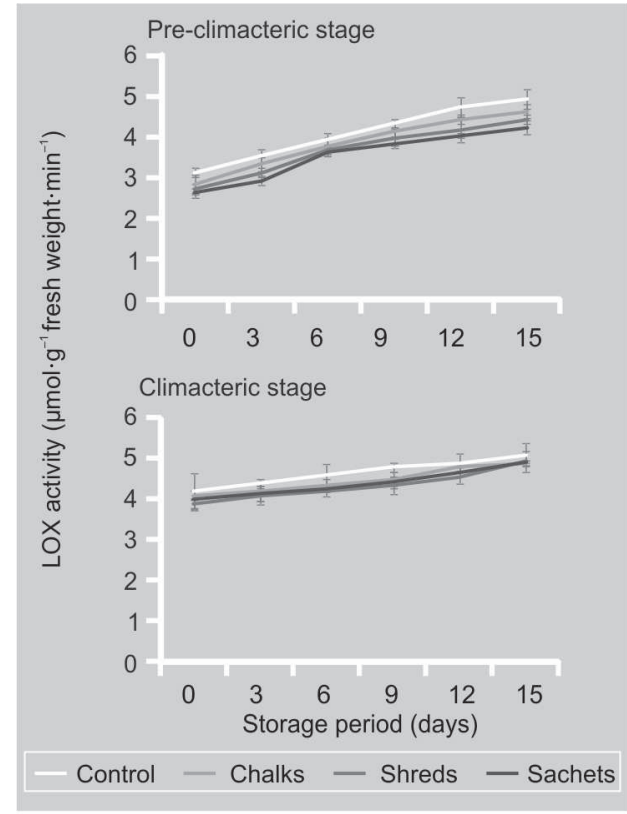

Figure 4.

Effect of ethylene absorbents on LOX activity of Japanese plum cv. 'Santa Rosa', according to the preclimacteric or climacteric stage of maturity. The fruits were packed with ethylene absorbents during transportation, after about $4 \mathrm{~h}$ of harvesting. After treatment, fruits were transported by road for about $15 \mathrm{~h}$ and then stored in the lab for 15 days in supermarket conditions $\left[(20 \pm 1){ }^{\circ} \mathrm{C}\right.$ and at $(90 \pm 2) \%$

$\mathrm{RH})$ ]. The data are means of five samples (fruits) with three replications, recorded at 3-day intervals. The bars represent the mean \pm standard error. ents were kept. However, the minimum LOX activity was observed in plums in which ethylene-absorbent sachets were placed for both stages of maturity. The other ethylene absorbents showed intermediate results for LOX activity in plums of both stages of maturity (figure 4$)(P \leq 0.05)$. The LOX activity increased progressively with the increase in storage period, the maximum being on the 15th day of storage.

Higher LOX activity in the climacteric stage of fruit maturity may be due to the fact that these plums were more active metabolically than plums of pre-climacteric maturity. The significant reduction effects of ethylene absorbents on LOX activity in plums may be ascribed to their effects on delaying the ripening process by absorbing the ethylene produced inside the box. Further, LOX activity increased progressively with the increase in storage period in both the stages of maturity, the maximum being on the 15 th day of storage, which might be due to progressive increase in fruit senescence with the storage period [19, 20].

\subsubsection{Polygalacturonase activity}

Polygalacturonase (PG) is an important enzyme responsible for fruit softening. With reduced PG activity, fruit softening is 
Figure 5.

Effect of ethylene absorbents on PG activity of Japanese plum cv. 'Santa Rosa', according to the preclimacteric or climacteric stage of maturity. The fruits were packed with ethylene absorbents during transportation, after about $4 \mathrm{~h}$ of harvesting. After treatment, fruits were transported by road for about $15 \mathrm{~h}$ and then stored in the lab for 15 days in supermarket conditions $\left[(20 \pm 1){ }^{\circ} \mathrm{C}\right.$ and at $(90 \pm 2) \%$ $\mathrm{RH})$ ]. The data are means of five samples (fruits) with three replications, recorded at 3-day intervals. The bars represent the mean \pm standard error.

Figure 6.

Effect of ethylene absorbents on PME activity of Japanese plum cv. 'Santa Rosa', according to the preclimacteric or climacteric stage of maturity. The fruits were packed with ethylene absorbents during transportation, after about $4 \mathrm{~h}$ of harvesting. After treatment, fruits were transported by road for about $15 \mathrm{~h}$ and then stored in the lab for 15 days in supermarket conditions [(20 \pm 1$)^{\circ} \mathrm{C}$ and at $(90 \pm 2) \%$ $\mathrm{RH})]$.The data are means of five samples (fruits) with three replications, recorded at 3-day intervals. The bars represent the mean \pm standard error.
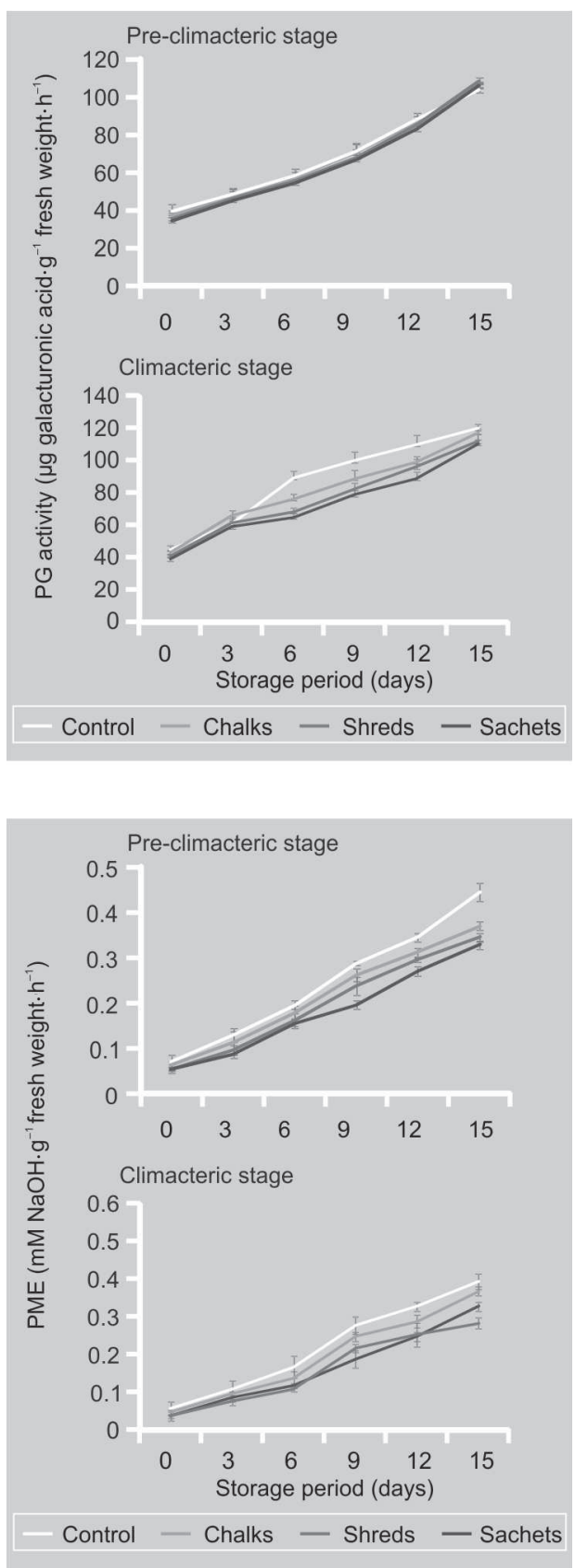

delayed, which increases the shelf life of fruit. Our study showed that, whatever the stage of harvest or storage period of plums, the PG activity was significantly higher in plums harvested at the climacteric stage than in those harvested at the pre-climacteric stage of maturity (figure 5). Similarly, PG activity was significantly higher in untreated plums at both stages of maturity than in those in which different ethylene absorbents were kept. PG activity was significantly lower in plums in which ethyleneabsorbing sachets were placed at both stages of maturity. The other absorbents $\left(\mathrm{KMnO}_{4}\right.$-impregnated chalks and newspaper shreds) showed intermediate results for PG activity in both stages of maturity (figure 5) $(P \leq 0.05)$. The PG activity showed a continuous increase with the increase in storage period in both stages of maturity, the maximum being on the 15 th day of storage, which might be due to progressive increase in fruit senescence and fruit softening [19, 20].

Higher PG activity in plums of the climacteric stage and those in which ethylene absorbents were placed may be due to lesser fruit softening. Ethylene absorbents, especially sachets or $\mathrm{KMnO}_{4}$-impregnated shreds, might have absorbed some amount of evoluted ethylene from the plums, which might have delayed ripening and slowed down the PG activity.

\subsubsection{Pectin methylesterase activity}

Whatever the stage of harvest or storage period, the pectin methylesterase activity (PME) was significantly higher in plums harvested at the climacteric stage than in those harvested at the pre-climacteric stage of maturity (figure O). In general, the PME activity was significantly higher in untreated plums at both stages of maturity than those in which ethylene-absorbent sachets were placed with packing material (figure o). Among treatments, the minimum PME activity was observed in fruits in which sachets were placed in both stages of maturity. The other absorbents showed intermediate results for PME activity in both stages of maturity (figure $O)(P \leq 0.05)$. Irrespective of maturity stage or treatment, the PME activity increased with the increase in storage period in both the stages of maturity, the maximum being on the 15 th day of storage. Lower PME activity in plums packed with ethylene absorbents, especially sachets, may be ascribed to the inhibitory effects of absorbents on PME activity by absorbing liberated ethylene. PME activity increased with the increase in storage period in both the stages of maturity, the maximum being on 
the 15th day of storage (figure O). Progressive increase in PME activity with the increase in storage period in both the stages of maturity may be ascribed to progressive softening of plums with increased storage period [19, 20].

\section{References}

[1] Chattophdayy T.K., A textbook on pomology, Vol. IV, Kalyani Publ., Ludhiana, India, 2008.

[2] Dick E., Adopo A.N., Camara B., Moudioh E., Influence of maturity stage of mango at harvest on its ripening quality, Fruits 64 (2009) 13-18.

[3] Lelievre J.M., Latche A., Jones B., Bouzayen M., Pech J.C., Ethylene and fruit ripening, Physiol. Plant. 101 (1997) 727-739.

[4] Valero D., Guillen F., Valverde J.M., MartinezRomero D., Castillo S., Serrano M., 1-MCP use on Prunus spp. to maintain fruit quality and to extend shelf life during storage: a comparative study, Acta Hortic. 682 (2005) 933-940.

[5] Menniti A.M., Gregori R., Donati I., 1methylcyclopropene retards postharvest softening of plums, Postharvest Biol. Technol. 31 (2004) 269-275.

[6] Jang K.I., Lee J.H., Kim K.Y., Jeong H.S., Quality of stored grape (Vitis labruscana) treated with ethylene absorbent and activated charcoal, Monogr. Korean Repub. 35 (2006) 1237-1244.

[7] Thakur K.S., Reddy V.C.M., Lal Kaushal B.B., Use of polyethylene box liners and ethylene absorbents for retention of quality of starking delicious apples during marketing, Acta Hortic. 696 (2005) 463-465.

[8] Liu F.W., Storage of bananas in polyethylene bags with an ethylene absorbent, HortScience 5 (1970) 25-27.

[9] Glahan S., Extending the shelf life of lychee using different $\mathrm{CO}_{2}: \mathrm{O}_{2}$ ratios and an ethylene absorbent in polyethylene bags, J. Agric. Technol. 2 (2006) 121-135.

[10] Jhalegar Md. J., Sharma R.R., Pal R.K., Rana V., Effect of postharvest treatments with polyamines on physiological and biochemical attributes of kiwifruit (Actinidia deliciosa). CV. Allison, Fruits 67 (2012) 13-22.

[11] Lazan H., Ali Z.M., Liang K.S., Yee K.L., Polygalacturonase activity and variation in ripening of papaya fruit with tissue depth and heat treatment, Physiol. Plant. 77 (1989) 9398.

[12] Hagerman A.E., Austin P.J., Continuous spectrophotometric assay for plant pectin methyl esterase, J. Agric. Food Chem. 34 (1986) 440-444.

[13] Panse V.G., Sukhatme P.V., Statistical methods for agricultural workers, ICAR, New-Delhi, India, 1984.

[14] Patel P.R., Rao T.V.R., Physiological changes in relation to growth and ripening of khirni (Manilkara hexandra) fruit, Fruits 64 (2009) 139-146.

[15] Ishaq S., Rathore H.A., Masud T., Ali S., Influence of postharvest calcium chloride application, ethylene absorbent and modified atmosphere on quality characteristics and shelf life of apricot (Prunus armeniaca L.) fruit during storage, Pak. J. Nutr. 8 (2009) 861-865.

[16] Pangaribuan D.H., Irving D.E., Hare T.J., Effect of an ethylene absorbent on quality of tomato slices, Australas. Postharvest Hortic. Conf. (2003) 251-252.

[17] Pekmezci M., Erkan M., Gubbuk H., Karasahin I., Uzun I., Modified atmosphere storage and ethylene absorbent enables prolonged storage of 'Hayward' kiwifruits, Acta Hortic. 632 (2004) 337-341.

[18] Paliyath G., Droillard M.J., The mechanism of membrane deterioration and disassembly during senescence, Plant Physiol. Biochem., 30 (1992) 789-812.

[19] Chin L.H., Ali Z.M., Lazan H., Cell wall modifications, degrading enzymes and softening of carambola fruit during ripening, J. Exp. Bot. 50 (1999) 767-775.

[20] Youmbi E., Zemboudem N.M., Tonfack L.B., Morphological and biochemical changes during development and maturation of Spondias cytherea fruit, Fruits 65 (2010) 285-292. 
Los absorbedores de etileno influencian la consistencia del fruto y la actividad de las enzimas implicadas en el reblandecimiento de las ciruelas japonesas (Prunus salicina Lindell) cv. Santa Rosa.

Resumen - Introducción. La ciruela japonesa cv. Santa Rosa tiene un comportamiento climatérico y se desarrolla bien en condiciones subtempladas de la India. Después de su maduración, tiene una vida útil muy limitada (3-4 días) en las condiciones ambientales $\left[(38 \pm 2)^{\circ} \mathrm{C}\right.$ y $(68 \pm 4) \% \mathrm{RH}$. Por lo tanto, sería urgente alargar su tiempo de conservación con ayuda de técnicas recientes. Material y métodos. Se cosecharon ciruelas japonesas en los estados de madurez preclimatérico y climatérico; y, se envolvieron en trozos de papel de periódico (tratamiento testigo), en tizas impregnadas de $\mathrm{KMnO}$, en trozos de papel de periódico impregnados de $\mathrm{KMnO} 4$ o en bolsas absorbedoras de etileno; a continuación, fueron transportadas por carretera hacia Nueva Delhi. Se efectuaron, con un intervalo de 3 días, un análisis bioquímico y uno fisiológico en las ciruelas almacenadas en condiciones de supermercado $\left[(20 \pm 1){ }^{\circ} \mathrm{C}\right.$ y $(90 \pm 2) \% \mathrm{RH}$ ] durante 15 días. Resultados y discusión. Los frutos sin absorbedores de etileno resultaron menos consistentes aquéllos envueltos con materiales absorbedores de etileno. Las actividades de las enzimas de reblandecimiento de los frutos, tales como la lipoxigenasa (LOX), la poligalacturonasa (PG) y la pectinmetilesterasa (PME), aumentaron rápidamente en los frutos testigo, en relación con los frutos envueltos con diferentes materiales absorbedores de etileno. Estas actividades fueron menores en las ciruelas envueltas con bolsas de absorbedores de etileno o con trozos de papel impregnado de $\mathrm{KMnO}_{4}$. Las ciruelas en los estados de madurez preclimatérico y climatérico alcanzaron sus picos de respiración y de evolución del etileno el $9^{\circ}$ día y el $6^{\circ}$ día, respectivamente. Conclusión. Las ciruelas japonesas cosechadas en los estados de madurez preclimatérico y climatérico, envueltas en presencia de bolsas absorbedoras de etileno y almacenadas en condiciones de supermercado, ofrecieron los mejores resultados en cuanto al mantenimiento de la consistencia, de la calidad y de la vida útil de los frutos, hasta el $12^{\circ}$ día y el $9^{\circ}$ día de almacenamiento, respectivamente.

India / Prunus salicina / frutas / aptitud para la conservación / firmeza / producción de etileno / fisiología postcosecha / actividad enzimática / lipoxigenasa / poligalacturonasa / esterasas 